\title{
Multimodal analgesia for pediatric patients who underwent open or laparoscopic appendectomy
}

\section{Açlk veya laparoskopik apendektomi uygulanan çocuk hastalarda multimodal analjezi}

\author{
Sengül ÖZMERT ${ }^{1}$, Feyza SEVER ${ }^{1}$, Ülkü ŞENEL YALÇIN ${ }^{2}$, Nurgül GÜLDAL ${ }^{2}$, Gülsen KESKİN${ }^{1}$, Mine AKIN ${ }^{1}$,

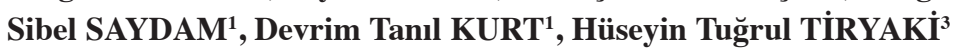

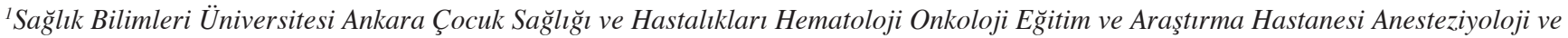
Reanimasyon Kliniği, Ankara, Türkiye

${ }^{2}$ Sağglı Bilimleri Üniversitesi Ankara Çocuk Sağlı̆̆ı ve Hastalıkları Hematoloji Onkoloji Ĕ̆itim ve Araştırma Hastanesi, Hemşirelik Hizmetleri, Çocuk Cerrahisi Klinĭ̆i, Ankara, Türkiye

${ }^{3}$ Sağlık Bilimleri Üniversitesi Ankara Çocuk Sağlı̆̆ı ve Hastalıkları Hematoloji Onkoloji Ĕ̆itim ve Araştırma Hastanesi, Çocuk Cerrahisi Kliniği, Ankara, Türkiye

\section{ABSTRACT}

Objective: The aim of this study is to show the results of the implementation of a multimodal pain therapy regimen consisting of preemptive and infiltration analgesia application to laparoscopic or open appendectomy in pediatric patients.

Methods: Eighty pediatric patients with diagnosis of acute and perforated appendicitis, who scheduled for laparoscopic or open appendectomy were randomly separated into 2 groups of 40. Age, sex, and weight of the patients, duration of anesthesia and surgical techniques were recorded. Preemptive $1.5 \mathrm{mg} / \mathrm{kg}$ tramadol HCl was administered at induction of anesthesia. As infiltration anesthesia $1 \mathrm{mg} / \mathrm{kg} 0.5 \%$ bupivacaine $\mathrm{HCl}$ was administered to the incision site of all patients. The pain levels of the patients after extubation were evaluated with Children's Hospital of Eastern Ontorio Pain Scale and Visual Analog Scale. The heart rates, respiratory rates, sedation score values, diastolic and systolic blood pressure values, postoperative analgesic requirements, sedation scores, the observed side effects, hospital stay, and the time of the first mobilization were recorded and compared.

Results: There were no statistically significant differences between the groups with respect to monitored parameters except operation time and anesthesia time. Postoperative first day 13 patients $(32.5 \%)$ in the LA group and in 9 patients (22.5\%) in OA group, while on the second day only 2 patients $(\% 5)$ in the $\mathrm{OA}$ group required additional analgesia .

Conclusion: Our multimodal analgesia protocol consisting of preemptive analgesia and perioperative local anesthesia infiltration showed no difference between patients who underwent laparoscopic or open appendectomy with respect to pain levels and analgesic requirements.

Keywords: Pediatric surgery, appendectomy, multimodal analgesia, preemptive analgesia

ÖZ

Amaȩ: Araştırmanın amacı, laparoskopik veya açık apendektomi uygulanan çocuk hastalarda, preemptif ve infiltrasyon analjezisinden oluşan multimodal ağrı tedavisinin sonuçlarını göstermektir.

Yöntem: Akut veya perfore appendisit tanısı olan, açı veya laparokopik yöntemle operasyonu planlanan 80 çocuk hasta rastgele 40 kişilik 2 gruba ayrıldı. Yaş, cinsiyet, ağırlık, anestezi süresi ve uygulanan cerrahi teknik kaydedildi. Anestezi indüksiyonu sırasinda preemptif olarak 1,5 $\mathrm{mg} / \mathrm{kg}$ tramadol HCl uyguland. Bütün hastalara infiltrasyon anestezisi insizyon bölgesine $1 \mathrm{mg} /$ $\mathrm{kg} \% 0,5$ bupivacaine $\mathrm{HCl}$ yapılarak uygulandı. Ekstübasyon sonrası hastaların ağrı düzeyleri Children's Hospital of Eastern Ontorio Pain Scale and Visual Analog Scale ile değerlendirildi. Kalp hızları, solunum sayıları, sedasyon skorları, sistolik ve diastolik kan basınçları, postoperatif analjezik gereksinimi, yan etkiler, hastanede yatış süreleri ve ilk mobilizasyon zamanları kaydedildi ve karşılaştırıldı.

Bulgular: Gruplar arasında takip edilen parametrelerde ameliyat süresi ve anestezi süresi hariç anlamlı farklılık saptanmadı. Laparoskopi grubunda 13 hastada $(\% 13,5)$ ve açık grupta 9 hastada $(\% 22,5)$ ek analjezik gereksinimi olurken, ikinci gün yalnızca açık grupta 2 hastada $(\% 5)$ analjezik ihtiyaçı oldu.

Sonuç: Preemptif analjezi ve lokal anestezik infiltrasyonunu içeren multimodal analjezi protokolümüz ile laparoskopik veya açık apendektomi uygulanan hastalar arasında, ağrı seviyesi ve analjezik gereksinimi yönünden farklılık saptanmadı.

Anahtar kelimeler: Çocuk cerrahisi, apendektomi, multimodal analjezi, preemptif analjezi
Alındığı tarih: 29.03 .2018

Kabul tarihi: 28.04 .2018

Yazışma adresi: Uzm. Dr. Sengül Özmert, Ankara Çocuk Sağlığı ve Hastalıkları Hematoloji Onkoloji Ḝitim ve Araştırma Hastanesi Anesteziyoloji ve Reanimasyon Kliniği, Dışkapı - 06100 Ankara Türkiye

e-mail: sengulozmert@yahoo.com.tr 


\section{INTRODUCTION}

Appendectomy is a frequently performed surgical procedure in children ${ }^{(1)}$. In many publications on laparoscopic appendectomy (LA) a lower requirement for postoperative analgesia shorter hospital stay, less wound infection and the earlier return to normal activity relative to open appendectomy (OA) have been reported ${ }^{(2,3)}$. Laparoscopic appendectomy (LA) has been performed routinely in pediatric patients for more than 10 years ${ }^{(2)}$. However, prospective randomized studies in children are limited ${ }^{(4)}$. This paper presents the results of the implementation of a multimodal pain therapy regimen consisting of preemptive application of local infiltration anesthesia to pediatric patients who underwent laparoscopic or open surgery appendectomy. The aim of the present study is to evaluate postoperative pain and its effects on first mobilization, and hospitalization time.

\section{MATERIAL and METHOD}

This prospective study included 80 consecutive pediatric patients aged 5-17 years with a diagnosis of acute and perforated appendicitis who underwent LA or OA between January 2013 and August 2013. Patients with communication and mental problems were excluded from the study. The study was approved by the hospital Local Ethics Committee (2013/020). Written informed consent was obtained for all subjects from a legal surrogate or the parents. Eighty patients were randomly separated into 2 groups of 40 to be operated with laparoscopic or open surgical technique. Age, sex, and weight of the patients, duration of anesthesia and surgical techniques were recorded. As infiltration anesthesia $1 \mathrm{mg} / \mathrm{kg}$ $0.5 \%$ bupivacaine $\mathrm{HCl}$ was administered to the incision site of all patients before incision. Induction of anesthesia for all patients was applied with $2.5 \mathrm{mg} / \mathrm{kg}$ propofol $1 \%, 0.5 \mathrm{mg} / \mathrm{kg}$ atracurium besylate, $1 \mathrm{mcg} /$ $\mathrm{kg}$ fentanyl citrate and preemptive administration of $1.5 \mathrm{mg} / \mathrm{kg}$ tramadol $\mathrm{HCl}$. Anesthesia was maintained with 2-3\% sevoflurane in $50 \% \mathrm{O}_{2}-50 \% \mathrm{~N}_{2} \mathrm{O}$.

Open appendectomy was performed with a Rockey Davis incision. The mesoappendix was determined and dissected, and the appendix was excised. The wound was closed in the anatomical planes.

Laparoscopic appendectomy was applied using 3 trocars. The first trocar inserted to achieve pneumoperitoneum. The pressure was set at a standard level. In both groups, the abdominal skin incisions were closed with sterile sponge dressings .

In the study, the recording of postoperative pain was standardized for both groups with daily monitoring of postoperative pain scores and analgesic requirements.

The pain levels of the patients after extubation were evaluated. The nurses who had the same education level individually, and blindly observed and assessed patients' pain perception levels for 48 hours postoperatively $(15,30$ minutes, 1, 2, 4, 6, 8, 12, 24, 36,48 hours) and evaluated the pain scale using Children's Hospital of Eastern Ontorio Pain Scale (CHEOPS) ${ }^{(5)}$. Assesment of the patients' age and their compliance with Visual Analog Scale (VAS) which consists of a horizontal line, the left end representing "no pain" $(0 \mathrm{~cm})$ and the right end representing "the worst imaginable pain" $(10 \mathrm{~cm})$, was used to score patients'perception of pain at same time intervals ${ }^{(6)}$. The patients discharged before 48 hours were evaluated during their hospitalization period.

During the follow-up period, when VAS scores were $>4$ and /or CHEOPS $>7,1 \mathrm{mg} / \mathrm{kg}$ tramadol $\mathrm{HCl}$ was administered. Postoperative analgesic requirements, sedation scores, the observed side effects, hospital stay, and the time of the first mobilization were recorded. The recorded parameters were analyzed statistically. Patients in both groups were discharged when they were afebrile, and could tolerate normal diet without abdominal tenderness.

\section{Statistical Analysis}

Sample size was calculated at least for 40 patients when power was taken as $80 \%$, type I error as 0.05 and expected difference as $\pm 20 \%$ for percentage of severe pain ( $\mathrm{R}$ 3.0.1. open source programme). Data were evaluated using SPSS version 11.5 (Chicago Inc. IL, USA) package programme. To compare differences between the LA and OA groups, the Independent samples t-test was used for continuous 
data with normal distribution, Mann-Whitney U-test for continuous data with non-normal distribution or ordinal data, and the chi-square test or Fisher-Exact test were used for categorical data. Repeated measures two-way ANOVA was used for hemodynamic parameters depending on time. Descriptive statistics were expressed as mean \pm standard deviation for continuous data with normal distribution, and median and interquartile range for continuous data with nonnormal distribution. Categorical data were expressed as frequencies and percentages $\mathrm{A}$ value of $\mathrm{p}<0.05$ was accepted as statistically significant.

\section{RESULTS}

A total of ASA I-II 80 patients with a mean age of $11.44 \pm 3.70$ years (range, 5-17 years) were prospectively examined in the study. The two groups comprised equal number of patients who underwent LA or OA. The female to male ratio was 0.54 (28 female / 52 male). In the comparison between the two groups, there was no significant difference in terms of age, gender, weight and ASA scores. Rates of acute and perforated appendicitis were similar between the two groups. Anesthesia and operative times were significantly different between the groups (Table 1).

Table 1. Descriptive data of all the patients.

\begin{tabular}{lccc}
\hline & $\begin{array}{c}\text { Lap. }(\mathbf{n}=40) \\
\text { Mean } \pm \text { SD }\end{array}$ & $\begin{array}{c}\text { Open }(\mathbf{n}=40) \\
\text { Mean } \pm \text { SD }\end{array}$ & P \\
\hline Gender M/F & $26 / 14$ & $26 / 14$ & 1,000 \\
Age (year) & $11,53 \pm 3,80$ & $11,35 \pm 3,61$ & 0,833 \\
Weight (kg) & $41,28 \pm 15,02$ & $41,38 \pm 16,52$ & 0,977 \\
ASA & & & \\
I & $33(\% 82,5)$ & $31(\% 77,5)$ & 0,576 \\
II & $7(\% 17,5)$ & $9(\% 22,5)$ & 0,001 \\
Anes. Time (min) & $60,65 \pm 13,65$ & $43,18 \pm 12,22$ & 0,001 \\
Surg. Time (min) & $46,48 \pm 13,56$ & $30,75 \pm 12,16$ & 0,787 \\
First mobilization time (hour) & $10,83 \pm 6,51$ & $11,20 \pm 5,85$ & 1,000 \\
Hospitalisation (day) & $2,20 \pm 1,09$ & $2,33 \pm 1,44$ & \\
& & &
\end{tabular}

Mean $\pm S D$ was shown as mean \pm standart deviation.

The duration of anesthesia was significantly different but additional fentanyl citrate was not needed peroperatively in both groups.

When the distribution of perforated and acute appendicitis between groups were examined, it was seen that 10 patients in the OA, and 9 patients in the LA group had perforated appendicitis without any statistically significant intergroup difference $(\mathrm{p}<0.05)$.

There were no significant differences between the groups as for the heart rates, respiratory rates, sedation score values, diastolic and systolic blood pressure values during the study.

VAS and CHEOPS values were recorded throughout postoperative 48 hours without any significant differences between the groups (Table 2).

Table 2. Pain scale values throughout the follow-up period.

\begin{tabular}{|c|c|c|c|c|c|c|}
\hline & \multicolumn{3}{|c|}{ VAS } & \multicolumn{3}{|c|}{ Cheops } \\
\hline & $\begin{array}{l}\text { Lap. } \\
\text { Med. } \\
\text { (IQR) }\end{array}$ & $\begin{array}{l}\text { Open } \\
\text { Med. } \\
\text { (IQR) }\end{array}$ & $\mathbf{P}$ & $\begin{array}{l}\text { Lap. } \\
\text { Med. } \\
\text { (IQR) }\end{array}$ & $\begin{array}{l}\text { Open } \\
\text { Med. } \\
\text { (IQR) }\end{array}$ & $\mathbf{P}$ \\
\hline $15 \mathrm{~min}$ & $3,5(3,75)$ & $4(2)$ & 0,942 & $5(1)$ & $6(1,75)$ & 0,074 \\
\hline $30 \mathrm{~min}$ & $4(3)$ & $4(3)$ & 0,922 & $5(1)$ & $5(1)$ & 0,208 \\
\hline $1 \mathrm{~h}$ & $3(2)$ & $4(2,75)$ & 0,538 & $5(1)$ & $5(1)$ & 0,193 \\
\hline $2 \mathrm{~h}$ & $3(2,75)$ & $3,5(2,75)$ & 0,938 & $5(1)$ & $5(1)$ & 0,467 \\
\hline $4 \mathrm{~h}$ & $3(2,75)$ & $3(3)$ & 0,829 & $5(1)$ & $5(1)$ & 0,160 \\
\hline $6 \mathrm{~h}$ & $3(1,75)$ & $3(2,75)$ & 0,929 & $5(1)$ & $5(1,75)$ & 0,234 \\
\hline $8 \mathrm{~h}$ & $2(2)$ & $2,5(2,75)$ & 0,508 & $5(1)$ & $5(1)$ & 0,227 \\
\hline $12 \mathrm{~h}$ & $2(2,75)$ & $2(3)$ & 0,254 & $5(1)$ & $5(1)$ & 0,899 \\
\hline $24 \mathrm{~h}$ & $1(2)$ & $1,5(2)$ & 0,623 & $4(1)$ & $4,5(1)$ & 0,301 \\
\hline $36 \mathrm{~h}$ & $0,5(2)$ & $1(2)$ & 0,735 & $4(1)$ & $4(1)$ & 0,569 \\
\hline $48 \mathrm{~h}$ & $1(2)$ & $1(1)$ & 0,608 & $4(0)$ & $4(1)$ & 0,186 \\
\hline
\end{tabular}

Med.(IQR): Median (Interquartil range)

Thirteen patients $(32.5 \%)$ in the LA , and 9 patients $(22.5 \%)$ in the OA group required additional analgesia on the postoperative first day. However, on the postoperative second day only 2 patients (\%5) which were in the OA group, needed additional analgesia. No patient in the LA group required additional analgesia.

When the patients were evaluated as for additional analgesia during the whole postoperative period, additional analgesia was administered twice to 5 patients in the OA group, and twice, and thrice to 3 patients, and once to one patient in the LA group, the other remaining patients receive additional analgesia only once.

In the LA group, 6 patients $(11.8 \%)$ needed tramadol $\mathrm{HCl}$ at the postoperative $15^{\text {th }}$ minute, while no patients in the OA group needed tramadol HCL at the same time. Analgesia and pain scores were similar in 
both groups at the postoperative 15 minutes (Table 2).

Six patients in the laparoscopic, and 2 patients in the open surgery groups had fever, and preoperatively received paracetamol. For 2 febrile patients in the OA group paracetamol was used on the first postoperative day.

In addition, there were no significant differences between the patients with perforated appendicitis and the those with acute appendicitis in terms of postoperative analgesia requirement. All patients were encouraged to return to unrestricted normal activity and there were no significant differences between the groups as for postoperative mobilization time. In respect of early postoperative complications, fever, wound infection and abscess formation were evaluated. There were no significant differences between the groups in terms of complications and the length of hospital stay (Table 1).

\section{DISCUSSION}

Laparoscopic appendectomy is the most common emergency procedure in children ${ }^{(1-3)}$. In a metaanalysis by Jen et al, while the rate of LA surgery was $19 \%$ in pediatric patients in 1999 , by 2006 , it had become an equally preferred surgical treatment with OA with a rate of $52 \%{ }^{(7)}$. Due to this development, the studies on the pediatric patients undergoing LA are increasing day by day.

In studies which mentioned the superiority of LA over $\mathrm{OA}$ in the literature it has been reported that postoperative pain is less than OA, which allows earlier mobilization and earlier discharge. Studies have indicated that total parenteral and oral analgesia requirements are less in the LA group ${ }^{(8,9)}$. Postoperative pain treatment can be stopped 1.1 days earlier on average in the LA group compared to the patients who received $\mathrm{OA}^{(10)}$. Schmelzer et al. ${ }^{(11)}$ reported that IV pain relief was required for 0.8 days in the LA group, while the patients in the OA group required IV pain relief twice longer period (1.9 days). Till et al. ${ }^{(12)}$ found that there is significantly less need for use of narcotics in the patients in LA group in a study on pediatric patients by using the PCA method.
It is a clinical reality that pain is an important complaint during the postoperative period among patients undergoing LA. Moreover, Tomecka et al. ${ }^{(13)}$ found that children who underwent LA had a substantial pain at 1: 3 ratio on the first, and 1: 5 on the second postoperative day. Therefore, the development of pain therapy regimens that can be reliably applied to the pediatric patients who have undergone $\mathrm{OA}$ as well as to children who are treated with LA is an important need.

There are many treatments such as non-steroidal anti-inflammatory drugs, opioids, corticosteroids and topical medications used during and after surgery for postoperative pain management ${ }^{(14)}$. Several treatment protocols have been developed in recent years, including preemptive analgesia, preventive analgesia, and multimodal analgesia in the treatment of postoperative pain ${ }^{(15)}$. The advantage of preemptive analgesia, which can be described as analgesic treatment initiated prior to surgical trauma, has been demonstrated with randomized studies performed during pre- and post-incisional period ${ }^{(16)}$. In recent years, there have been many studies supporting its use and concerning prevalence of preemptive analgesia, especially in pediatric patients ${ }^{(17)}$. However, until now, the effect of tramadol and bupivacaine combination treatment on postoperative pain in appendectomy patients has not been investigated.

Tramadol, which is in the weak opioids group in the classification of analgesics is a dual-acting synthetic drug with both opioid and non-opioid mechanisms of action and this additive effect obtained by these two mechanisms enables it widespread use in the treatment of moderate-to-severe pain thanks to its significant anti-nociceptive activity and favourable side effect profile ${ }^{(18)}$. Literature on the use of preemptive tramadol in children is very limited. Van der Berg et al. ${ }^{(19)}$ compared the preemptive analgesic effect and side effects of tramadol, pethidine and nalbuphine in pediatric patients and found that patients receiving nalbuphine and tramadol returned to spontaneous respiration more easily, but adverse side effects such as nausea and vomiting were more frequent in the nalbuphine group, while doses of $\geq 3 \mathrm{mg}$ / $\mathrm{kg}$ tramadol resulted in nausea and vomiting. Özköse 
et al. ${ }^{(20)}$ have shown that administration of low doses of tramadol at a dose of $0.5-1 \mathrm{mg} / \mathrm{kg}$ during induction to pediatric patients who undergo adenotocillectomy provides effective postoperative analgesia. The information we obtained from the results of our administration of $1.5 \mathrm{mg} / \mathrm{kg}$ tramadol dose in our study revealed that tramadol at indicated dosed provided sufficient preemptive analgesia in our patients. Side effects such as vomiting and sedation, which are common in tramadol use, have not been found in any of our patients.

Bupivacaine is an amide group local anesthetic with long efficacy and wide application area and its positive effects on postoperative pain via its preincisional use in tonsillectomy applied children under general anesthesia, has been known for a long time (21). The positive effects of infiltration on the wounds in abdominal operations are well known in adult patients ${ }^{(22)}$. Cervini et al. ${ }^{(23)}$ has shown that the use of intraoperative bupivacaine infiltration in patients undergoing laparoscopic appendectomy reduced postoperative pain and narcotic use. However, it is known that the postoperative analgesic needs of adult patients and pediatric patients undergoing appendectomy are different, and it is not appropriate to consider the studies done in adult patients correspond exactly to those performed in pediatric patients ${ }^{(24)}$. As a matter of fact, Wright et al. ${ }^{(25)}$ showed in a controlled study of appendectomized children, bupivacaine infiltration significantly reduced postoperative pain. In our study, we think that reaching the same pain level of LA group in the OA group depends on the local bupivacaine effect. Similarly in a retrospective study, Liu et al. ${ }^{(26)}$ reported that using multimodal analgesia with local anesthesia was effective in reducing pain in pediatric patients following laparoscopic appendectomy.

The multimodal analgesia protocol that we used in our study was a combination of preemptive analgesia and local infiltration analgesia. We couldn't find any study in the literature in which this multimodal analgesia protocol has been used. In our study, postoperative pain was assessed while considering the difficulty of pain assessment in children and VAS and CHEOPS pain scales as well as hemodynamic monitoring were taken into account. In our study, we aimed to provide pain treatment which we believed to be effective in all patients by applying the same standard analgesic regimen in both groups and therefore we did not consider it appropriate to create a control group. We compared OA, and LA groups as for VAS, CHEOPS pain scale scores and haemodynamic values and found that there is less postoperative pain in the LA group in general.

There are controversies about length of hospital stay, time to return to normal activity and complications between OA and LA in the literature ${ }^{(7)}$. Most of the publications have claimed that LA leads to shorter hospital stay, earlier return to normal activity and lower number of complication than open appendectomy ${ }^{(4)}$. We accept that effective standardised multimodal analgesia regimen and perioperative local anesthesia infiltration achieve early postoperative mobilization in both groups. In a comparative study of pediatric patients by $\mathrm{Li}$ et al. ${ }^{(10)}$ it was reported that patients undergoing LA, had a shorter hospital stay compared to OA patients. In 2010 a metaanalysis of 95,806 pediatric appendectomies, Jen et al. (7) determined that the risk of postoperative abscess formation increased in the LA group. On the other hand, length of hospital stay was shorter in the LA group. In our study, there were no difference in hospital stay and time to return to daily activities between LA and OA groups. We think that the significant length of anaesthesia and operative time of laparoscopic appendectomy will be equalized between the two groups by the increase of our experience of laparoscopic appendectomy.

Standardised multimodal analgesia protocol consisting of preemptive analgesia and perioperative local anesthesia infiltration is used in LA and OA in pediatric patients for postoperative pain control. This single-blind, prospective, randomized clinical research study showed no difference between the patients who underwent laparoscopic or open surgery in respect of pain levels and analgesic requirements after appendectomy. Besides, there were no significant differences between the patients with perforated appendicitis and the patients with acute appendicitis in terms of postoperative analgesia. 


\section{REFERENCES}

1. Addiss DG, Shaffer N, Fowler BS, Tauxe RV. The epidemiology of appendicitis and appendectomy in the United States. Am J Epidemiol. 1990;132:910-25. https://doi.org/10.1093/oxfordjournals .aje.a115734

2. El Ghoneimi A, Valla JS, Limonne B, Valla V, Montupet P, Chavrier Y, et al. Laparoscopic appendectomy in children: report of 1379 cases. J Pediatr Surg. 1994;29:786-9. https://doi.org/10.1016/0022-3468(94)90371-9

3. Blakely ML, Spurbeck WW, Lobe TE. Current status of laparoscopic appendectomy in children. Semin Pediatr Surg. 1998;7:225-7. https://doi.org/10.1016/S1055-8586(98)70035-6

4. Esposito C, Borzi P, Valla JS, Mekki M, Nouri A, Becmeur F, et al. Laparoscopic versus open appendectomy in children: a retrospective comparative study of 2,332 cases. World J Surg. 2007;31:750-5. https://doi.org/10.1007/s00268-006-0699-8

5. Mc Garth PJ, Johnson G, Goodman JT, Schillinger J, Dunn J, Chapman J-A. CHEOPS: A behavioral scale for rating postoperative pain in children. In Fields HL, Dubner R, Carvero F (eds). Advances in Pain Reaserch and Theraphy. New York, Roven Press, 1985. p. 395-402.

6. Albersnagel FA. Velten and musical mood induction procedures: a comparison with accessibility of thought associations. Behav Res Ther. 1988;26:79-96. https://doi.org/10.1016/0005-7967(88)90035-6

7. Jen HC, Shew SB. Laparoscopic Versus Open Appendectomy in Children: Outcomes Comparison Based on a Statewide Analysis Journal of Surgical Research. 2010;161:13-7.

8. Pedersen AG, Petersen OB, Wara P, Rønning H, Qvist N, Laurberg S. Randomized clinical trial of laparoscopic versus open appendicectomy. Br J Surg. 2001;88:200-5. https://doi.org/10.1046/j.1365-2168.2001.01652.x

9. Marzouk M, Khater M, Elsadek M, Abdelmoghny A. Laparoscopic versus open appendectomy: a prospective comparative study of 227 patients. Surg Endosc. 2003;17:721-4. https://doi.org/10.1007/s00464-002-9069-2

10. Li P, Xu Q, Ji Z, Gao Y, Zhang X, Duan Y, et al. Comparison of surgical stress between laparoscopic and open appendectomy in children. J Pediatr Surg. 2005;40:1279-83. https://doi.org/10.1016/j.jpedsurg.2005.05.011

11. Schmelzer TM, Rana AR, Walters KC, Norton HJ, Bambini DA, Heniford BT. Improved outcomes for laparoscopic appendectomy compared with open appendectomy in the pediatric population. J Laparoendosc Adv Surg Tech A. 2007;17:693-7. https://doi.org/10.1089/lap.2007.0070

12. Till H, Lochbuhler H, Lochbuhler H, Kellnar S, Bohm R, Joppich I. Patient controlled analgesia (PCA) in pediatric surgery: A prospective study following laparoscopic and open appendicectomy. Paediatr Anaesth. 1996;6:29-32. https://doi.org/10.1111/j.1460-9592.1996.tb00349.x

13. Tomecka MJ, Bortsov AV, Miller NR, Solano N, Narron J,
McNaull PP, et al. Substantial postoperative pain is common among children undergoing laparoscopic appendectomy Pediatric Anesthesia. 2012;22:130-5.

14. Paar WD, Frankus P, Dengler HJ. The metabolism of tramadol by human liver microsomes human liver microsomes. Clin Investig. 1992;70:708-10. https://doi.org/10.1007/BF00180294

15. Rosero EB, Joshi GP. Preemptive, preventive, multimodal analgesia: what do they really mean? Plast Reconstr Surg. 2014;134:85-93. https://doi.org/10.1097/PRS.0000000000000671

16. Penprase B, Brunetto E, Dahmani E, Forthoffer JJ, Kapoor S. The efficacy of preemptive analgesia for postoperative pain control: a systematic review of the literature. AORN J. 2015;101:94-105. https://doi.org/10.1016/j.aorn.2014.01.030

17. Sener M. Preemptive analgesia for acute postoperative pain management in children. Paediatr Anaesth. 2016;26:856. https://doi.org/10.1111/pan.12942

18. Bamigbade TA, Langford RM. The clinical use of tramadol hydrochloride. Pain Reviews. 1998;5:155-82. https://doi.org/10.1191/096813098668122984

19. Van den Berg AA, Montoya-Pelaez LF, Halliday EM, Hassan I, Baloch MS. Analgesia for adenotonsillectomy in children and young adults: a comparison of tramadol, pethidine and nalbuphine. Eur J Anaesthesiol. 1999;16:186-94. https://doi.org/10.1046/j.1365-2346.1999.00451.x

20. Ozkose Z, Akcabay M, Kemaloglu YK, Sezenler S. Relief of posttonsillectomy pain with low-dose tramadol given at induction of anesthesia in children. Int $\mathrm{J}$ Pediatr Otorhinolaryngol. 200014;53:207-14.

21. Jebeles JA, Reilly JS, Gutierrez JF, Bradley EL, Jr, Kissin I. The effect of pre-incisional infiltration of tonsils with bupivacaine on the pain following tonsillectomy under general anesthesia. Pain. 1991;47:305-58. https://doi.org/10.1016/0304-3959(91)90220-R

22. Ng A, Swami A, Smith G, Davidson AC, Emembolu J. The analgesic effects of intraperitoneal and incisional bupivacaine with epinephrine after total abdominal hysterectomy. Anesth Analg. 2002;95:158-62. https://doi.org/10.1097/00000539-200207000-00028

23. Cervini P, Smith LC, Urbach DR. The effect of intraoperative bupivacaine administration on parenteral narcotic use after laparoscopic appendectomy. Surg Endosc. 2002;16:1579-82. https://doi.org/10.1007/s00464-002-8803-0

24. Lambert, A.W, Mayor A. Analgesic requirements for appendicectomy: the differences between adults and children. Ann. R. Coll. Surg. Engl. 2000;82:67-8.

25 . Wright, J.E. Controlled trial of wound infiltration with bupivacaine for postoperative pain relief after appendicectomy in children. Br J Surg. 1993;80:110-11. https://doi.org/10.1002/bjs.1800800136

26. Liu Y, Seipel C, Lopez ME, Nuchtern JG, Brandt ML, Fallon $\mathrm{SC}$, et al. A retrospective study of multimodal analgesic treatmen after laparoscopic appendectomy in children. Paediatr Anaesth. 2013;23:1187-92. 